「わが社の新製品」特集

\title{
抗菌防臭天然系瀻維「キトポリイ」 富士紡績株式会社
}

\section{1. はじめに}

䇝維製品, 特に衣料品や寝装品において抗菌性や抗力 ビ性を具備したものが要求され，商品として多数出回る ようになった。われわれの生活空間の中にはたくさんの 微生物が存在しており, 細菌やカビと隣あわせで生活し ていると言っても過言ではない。䄉維製品に汗や老廃物 などが付着すると微生物が繁殖して悪臭を発したり，刺 激や皮病病を併発する原因となる。そこで抗菌加工（衛 生加工）が検討され，有機金属化合物をはじめ, 無機 物，金属塩，第 4 級アンモニウム塩などいろいろなもの が抗菌凪として用いられてきだ”。

ここ数年，地球環境保護に関する意識が高揚してきた ため単に安全性が確認されただけでなく, 環境污染を起 こさないエコロジカルな素材が注目されている。このよ うな背景において，当社では天然の多糖類“キトサン”を 用いた抗菌防臭綫維「キトポリイ」を開発したのでその 特性や用途について紹介してみたい。

\section{2. キトサンとは}

カニ・エビなどの甲殼類, カブト虫・バッ夕などの昆 蟖に多く存在するキチンの加水分解物であるキトサン はダルコサミンが $\beta-1,4$ 結合した多糖類であり，機能 性・反応性の高さから広範囲な用途開発が進んでいる 2)。特に化粧品分野ではシャンプー・リンスなどのへア ケア製品や乳液・クリームなどで，またスナック菓子に 添加して食品分野でも使用されている。 キトサンは有 機溶媒には安定であるが, 酢酸や塩酸などの有機酸・鉱 酸に容易に溶解する性質を持っている。このためキトサ ン酸性溶液をノズルから押出して䄉維・フィルム・ビー
田中兵作・瀬 尾寛

ズ等に再生することができる。また粒径数ミクロンの微 粒子状再生キトサンも得られ，これがキトポリイの原料 の一部として用いられている。これらのキトサンに関し て充分に高い安全性が報告されている3

\section{3. キトポリイの調製}

ポリノジックは一般のレーヨンと比べて重合度が高く このため高強力で低収縮な織維が得られ，また染色性も 高く改質レーヨンとして多用途に使われている。

キトサンを混入したポリノジック織維「キトポリイ」 は次のようにして得られる。

\section{1 キトポリイ䅉維の製造4)}

キトサン微粒子はビスコース段階でポリノジックに混 合される。すなわちポリノジック用セルロースキサント ゲン酸ソーダ溶液中にて混合され，その後ノズルを通過 するためノズルの孔径よりも細かいキトサン微粒子が必 要である。凝固・再生以降の条件は一般のポリノジック 䄳維製造条件に準じて行われる。得られたキトポリイ緎 維の表面拡大写真を図 1 に示す。キトサンを特殊染料で 発光させてあるため, ポリノジック䄉維の中に混入され たキトサンだけが白く光って見える。キトサンが扁平に 見えるのはキトサンが幾分膨潤しポリノジックと一体に なり，延伸工程で一緒に伸ばされたものと考える。キト サンが一体感をもってポリノジックと混合されているた め, 微粒子混入にもかかわらず強度の低下は認められて いない。このようにして現状 $1.25 \mathrm{~d} \times 38 \mathrm{~mm}$ のキトポリイ 䄉維（ステープル）を標準番手として製造している。

\section{2 キトポリイ使いの編織布・不蜮布など}

キトポリイ䄉維はカードや精紡機に代表される紡績機 械特性に優れているところからポリノジック緎維と同条

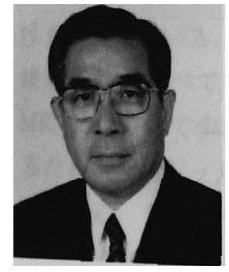

田中 兵作氏

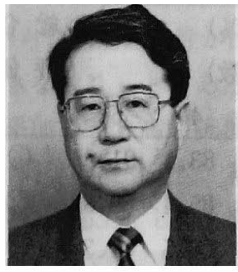

濑尾寛氏
'CHITOPOLY', Antimicrobial Fiber Made from Natural Materials 筆者紹介 HEISAKU TANAKA* and HIROSHI SEO**

*Fuji Spinning Co., Ltd.

** Institute of Research and Development, Fuji Spinning Co., Ltd. 富士紡績株式会社

田中氏は常務取締役，綫維工学を専門とされ，趣味は読書，旅行。

瀬尾氏は商品開発研究所 主任研究員, 高分子化学を專門とされ, 趣味はスポ ーツ, 音楽。

本稿では, キトサンの抗菌性能を活かした天然系の抗菌防臬䄉維「キトポリイ」 が生分解性能を有し,安全性が極めて高い素材であることを紹介していただいた。 


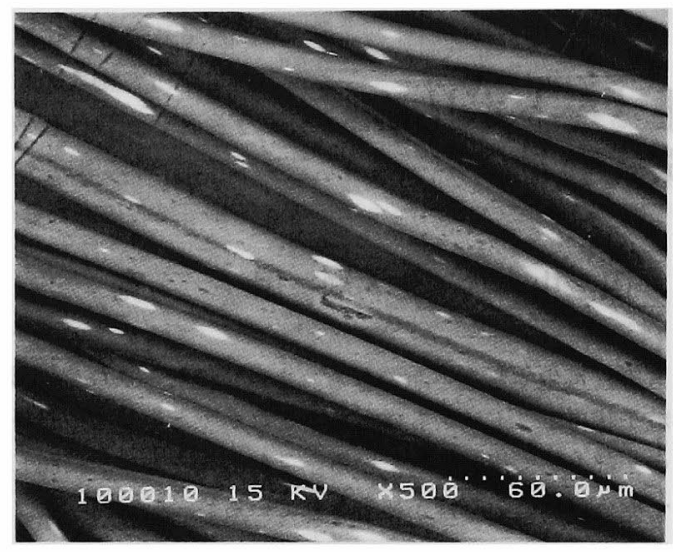

図1 キトポリイ表面の SEM 写真

写真の白く光っている部分がキトサンである。

件で紡績系が得られる。編機や織機に対する適性も高 く，薄ものから厚地まで対応することが出来る。また不 織布製造に関してもケミカルボンド・スパンレース・ス テッチボンド・ニードルパンチなど各種の不織布製造機 に対応可能である。さらに綿との混紡糸が可能であり, 加えてポリエステルやアクリルとの交織・交編も出来る ため製品群が織維製品全体に拡がることが期待される。

\section{4. 抗菌性}

綫維製品はほとんどが直接肌に触れるか，あるいは家庭 内や生活環境の中で使われるものである。このため抗菌 性を付与した織維製品において, 積極的な殺菌効果が発 揮されるようでは効果が強すぎて人体に何らかの悪影響 を及ほす可能性があると見られる傾向にある。従って抗 菌性および菌を抑えることによる防臭作用について次の ような取り決めがなされているので紹介しよう。

\subsection{SEK マーク}

緎維製品衛生加工協議会では抗菌防臭性能を有する䋐 維製品に対して，一定の性能と安全性をクリヤーしたも のに承認番号とともにSEK マークを付与している。
抗菌試験は黄色ブドウ状球菌（Staphylococcus aureus） あるいは肺炎桿菌（Klebsiella pneummiae）を試験菌株 として用いてシェークフラスコ法または菌数測定法で試 験することが義務つけけられている5)。

シェークフラスコ法は試験菌 $1 \sim 2 \times 10^{4} / \mathrm{m} \ell$ の㔠濁液を 調製したのち生菌数を測定する。次に $0.75 \mathrm{~g}$ の試験片を 加えて $25^{\circ} \mathrm{C}, 320 \mathrm{rpm}$ で 1 時間振复したのち再度生菌数 を測定し次式により減菌率を求める。 減菌率 $=\frac{\text { 振盪前の生菌数一振盪後の生菌数 }}{\text { 振盪前の生菌数 }} \times 100(\%)$

同様にして標準布を用いて減菌率を測定し, 試験試料 との減菌率の差が26\%以上あるとき抗菌性ありと判断す る。シェークフラスコ法は抗菌剤が振盪によって溶離す る場合に有利な試験法である。

菌数測定法は試験菌のブイヨン懸濁液を試験試料に注 加し(このときの植菌数を $\mathrm{A}$ とする。A $\mathrm{A}=5 \sim 30 \times$ $\left.10^{5} / \mathrm{m} \ell\right), 37^{\circ} \mathrm{C} て ゙ 18$ 時間培養後の生菌数Cを測定し, 植菌 数に対する増減值を対数で表す。次に標準布を用い下同 様に培養後の生菌数Bを測定し, 増減値を求める。炏式 により増隇值差を算出し 1.6 以上のとき抗菌性ありと判 断する。

$$
\text { 増減値差 }=(\log \mathrm{B}-\log \mathrm{A})-(\log \mathrm{C}-\log \mathrm{A})
$$

\section{2 抗菌性データ}

キトサンはカチオン性高分子であり元来抗菌性を持っ ている。キトサンを酢酸に溶解し SCD 培地に添加後, 菌を接種して $37^{\circ} \mathrm{C} て ゙ 48$ 時間培養した。培養液の濁度 (OD.660nm) がゼロの時のキトサン濃度を以て最小生 育阻止濃度 (MIC 值) とした。その結果潰瘍病菌 (Corinebacterium michiganence) は $10 \mathrm{ppm}$, 黄色ブドウ 状球菌, 大腸菌 (Escherichia coli), 単球菌 (Micrococcus luteus）はそれぞれ MIC 值20ppm と強い抗細菌性を示し だ)。

抗力ビ性について, 灰色力ビ病菌 (Botrytis cinerea) を用いて同様の方法（液体培養法）と寒天培養法とで MIC 值を測定した結果，それぞれ10ppm と $1,000 \mathrm{ppm}$ あった。また白症菌（Trichophyton equinumの MIC 值は

表 $1 「$ 「トポリイ」製品の抗菌性（菌株；肺炎桿菌）

\begin{tabular}{|c|c|c|c|c|c|c|c|c|c|c|}
\hline \multirow[b]{2}{*}{ 素 } & \multirow{2}{*}{$\begin{array}{l}\text { 試 } \\
\text { 材 }\end{array}$} & \multicolumn{2}{|l|}{ 料 } & \multicolumn{5}{|c|}{$\begin{array}{l}\text { 減 菌 率 }(\%) \\
\text { (洗 濯 回 数) }\end{array}$} & \multicolumn{2}{|r|}{$\begin{array}{l}\text { 総 合 } \\
\text { 評 価 }\end{array}$} \\
\hline & & 製 & 品 & 0 & 10 & 20 & 30 & 40 & 50 & \\
\hline キ & ポリイ/綿 & 肌 & 着 & 99.3 & 84.4 & 85.7 & 85.5 & 83.1 & 91.9 & 0 \\
\hline & ポリイ & & ル & 96.8 & 86.8 & 88.5 & 82.6 & 85.4 & 89.8 & 0 \\
\hline & ポリイ & 靴 & 下 & 98.4 & 93.5 & 91.2 & 87.6 & 88.5 & 84.3 & 0 \\
\hline
\end{tabular}


表2「キトポリイ」製品の抗菌性（菌株；黄色ブドウ状球菌）

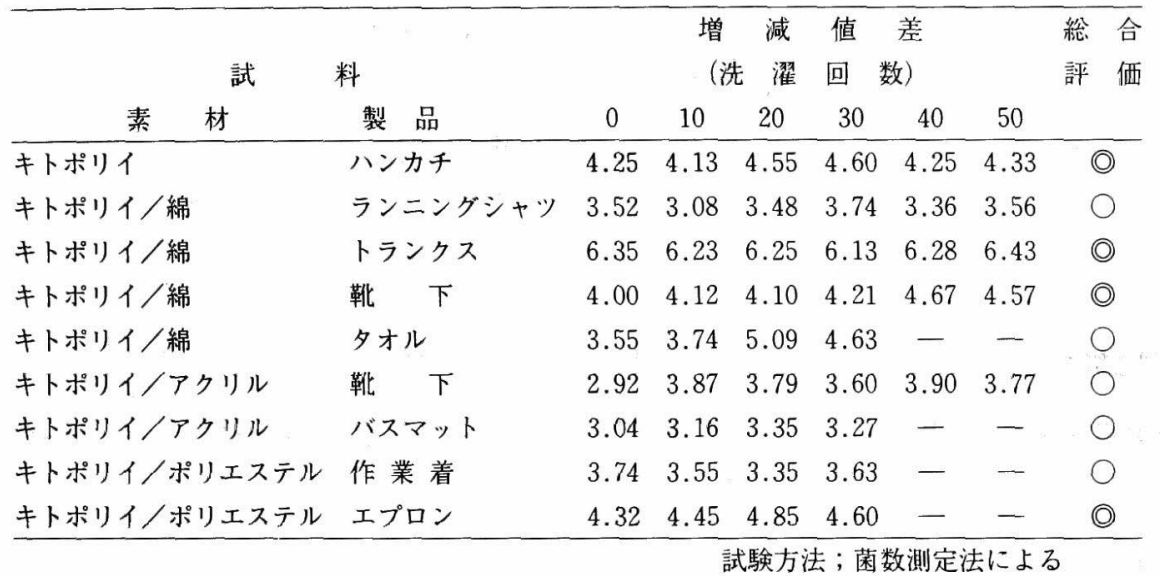

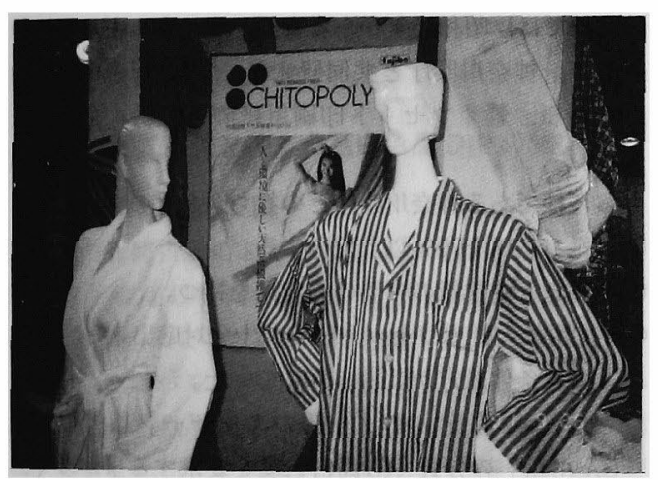

図2「キトポリイ」製品

寒天培養法で2,500ppmであり，キトサンは抗細菌性だ けでなく抗カビ性も持っていることが分かっだ)。

次にキトポリイ製品の抗菌性については，表 1 および 表 2 に示すようにシェークフラスコ法, 菌数測定法いず れも高い抗菌性が得られた。

\section{5. キトポリイの優位性}

キトポリイは原料段階でキトサンをポリノジックビス コースに混入して作られているため，ソフトな風合いを 具備し, ポリノジックの持つ絹のような光沢や高い吸湿 性も維持している。さらに洗濯耐久性が優れている点が 後加工品と比べて大きなメリットである。キトサンの MIC 值からして少量添加で充分高い抗菌効果が得られ るためポリノジックと同等の機械適性，織維物性が得ら れている。また染色等の後加工をしても高い抗菌性が得

\section{られる点も特長の一つである。}

キトポリイは抗細菌性と抗カビ性を併せ持ち, しかも 殺菌効果ではなく増殖抑制効果というマイルドな抗菌性 を示す。そしてキトポリイの最大の特長は, ポリノジッ クとキトサンがいずれも天然物由来の素材であり安全性 が高く，生分解性の素材ということである。人と環境に やさしくエコロジーブームに最適の素材と考えている。

\section{6. おわりに}

抗菌防舁天然系䋐維「キトポリイ」を発表してから半 年が経ち、この間天然系抗菌素材に対する関心の高さを 確信した。これは社会間題となっている地球環境保護に 対する関心と同一のものと判断している。

キトポリイは衣料品, 寝装品だけでなくバス\&ベッド 関連商品, サニタリー・トイレタリ一用品, 医療用品な ど幅広い展開が可能であり，社会のニーズを踏まえた商 品開発で大きく前進することを期待したい。

\section{引用文献}

1) 弓削 治; 染色工業, 30 (10)，478-484（1982）

2 ) 瀬尾 寛, 谷邊博昭; 「キチンキトサンの開発と応 用」189-201工業技術会（1987）

3 ）瀬尾 寛; 繊維学会誌, 46（12）564-569，（1990）

4) H. Seo et al ; Proceedings of the 5th International Conference on Chitin \& Chitosan, (Princeton NJ. USA; Oct. 1991)in Press.

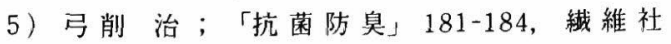
(1989) 